\section{Inkaba yeAfrica Project Surveys Sector of Earth from Core to Space}

\section{PAGES 113, 117}

In the Xhosa language, 'inkaba' means 'navel', the central point from which all energy, material, and knowledge emerge and are recycled. The word encapsulates a sense of total interconnectivity. Uniting inkaba with yeAfrica adds a regional perspective to a project that has as its central focus the understanding of the dynamic interactions between the Earth and its life-support systems.

Following two years of workshops and proposal writing, the German and South African Earth science communities embarked in 2004 on a five-year program, Inkaba yeAfrica, to survey a cone-shaped sector of the Earth from core to space, intersecting its solid surface around southern Africa and its ocean basins (Figure 1). The vision is to track the history of this sector's components back over at least the past 200 million years to understand Earth systems processes and their evolving interactions at different scales and rates.

The Inkaba yeAfrica project is unique. It takes a holistic and interdisciplinary view of the interactions between the solid Earth and its fluid envelope. Also, the project aims to meet the socioeconomic needs of South Africa and to reinvest in geodetic-linked infrastructures through the national radio astronomy and magnetic observatories (Hartebeesthoek Radio Astronomy Observatory and Hermanus Magnetic Observatory, respectively), in line with Africa's New Economic Program for African Development (NEPAD).

The scale and complexity of Inkaba yeAfrica set it apart from most Earth science efforts [Bohannon, 2004]. More than 100 Earth and space scientists from a consortium of 15 government and academic institutions in South Africa and Germany are now participating in this US \$30-million program.

\section{Why Southern Africa?}

Southern Africa is a unique systems 'laboratory' because it retains a well-preserved coevolving record of the Earth and life for the last 3.5 billion years. The region is also the current focus of research on very rapid changes in the Earth's magnetic field and on the origins of human creativity (the oldest known cultural artifacts, dated to 78,000 years, have been found along the country's southern coast). In addition, the continental margin is hugged by several interacting ocean currents that buffer severe climatic fluctuations and sustain these ideal conditions for social interaction.

Researchers also can benefit from southern Africa's unique oceanographic setting: The confluence of the warm Agulhas and the cold Benguela currents results in a complex mixing zone (Cape Cauldron) and the leakage of warm water rings into the Atlantic. Along the broad western continental shelf, the cold undercurrent system surfaces to sustain an adjacent desert and a region of high carbon sequestration.

Furthermore, the region's tectonic setting is also unique, dominated by a high plateau far away from compressive plate boundaries. This is the world's only example in an extensional environment of co-occurring active vertical plate movement (epeirogony) and intraplate seismicity, the origins of which are only vaguely understood.

Inkaba yeAfrica comprises 12 projects divided among three main research themesHeart of Africa, Margins of Africa, and Living Africa-and has a formal Capacity Building and Outreach Program (Table 1).

\section{Dynamic Systems Caught in the Act: Heart of Africa}

The Heart of Africa theme focuses on the transfer of energy from core to space. One project monitors geomagnetic field variations in this key region, using local observatories and satellites, like the German GeoForschungsZentrum satellite CHAMP, to explain and predict secular changes on a large scale. The satellite data show that a dramatic decrease of the Earth's magnetic field partly coincides with a South Atlantic anomaly where the geomagnetic field is significantly weaker than over the rest of the Earth at equivalent altitudes. This weak geomagnetic field in southern Africa severely reduces its shielding effect, allowing high-energy particles to penetrate deep into the upper atmosphere to altitudes below 100 kilometers. These particles can interfere with the communication systems of satellites and high-flying aircraft.

Continuous monitoring at the South African Hermanus Magnetic Observatory has documented a decrease in the magnetic field strength of about 26 percent since the 1920s. Concomitantly, the orientation of the geomagnetic field has changed rapidly across southern Africa in opposing directions, creating a spatial gradient over the subcontinent that is presently increasing with time. Improvements to the repeat station network are underway. In late 2005, new measurement campaigns were initiated to monitor the progress of a possible imminent magnetic reversal and to compile a detailed map of secular variations.

A second project seeks to reconstruct the evolution of southern Africa's dramatic landscapes in order to track details of deep mantle dynamics beneath the continent. This reconstruction could unravel suspected feedback between mantle upwelling, epeirogony, topography, and climate.

To quantify the region's geomorphic history, fission-track analyses and cosmogenic dating studies are in progress. Along the west coast, early results implicate fast uplift between 160 and 100 million years ago (Ma), whereas results from a 600-kilometer corridor-which stretches from the south coast northward and includes three deep boreholes in the Karoo basin-show that the 250-Ma Cape Fold Belt was exhumed in the Cretaceous Period, between 145 and $65 \mathrm{Ma}$.

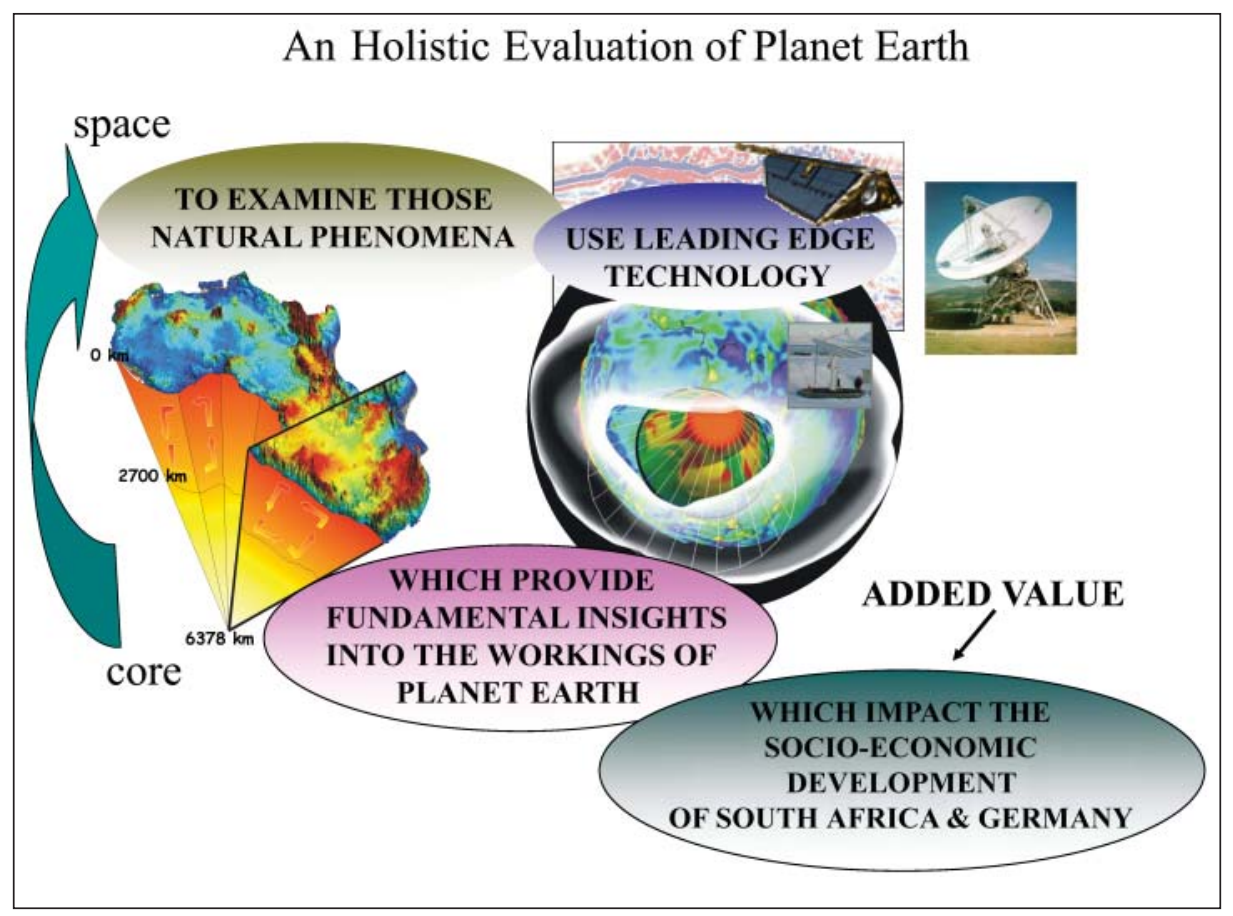

Fig. 1. Inkaba yeAfrica is a new program designed to investigate feedback systems in a coneshaped sector of the Earth from the core to space, that also dovetails with the socio-economic needs of southern Africa. 
Up to six kilometers of sediments that once covered the Cape Fold Belt and Karoo basin were eroded in two punctuated episodes: in the early Cretaceous (120-145 Ma) and in the mid-Cretaceous (80-100 Ma). The two exhumation events coincided with two peaks of intrusions of mantle-derived kimberlites (200 and 450 kimberlite pipes, respectively). Thus, for the first time, a direct link has been established in this region between increased regional erosion rates and punctuated episodes of positive mantle buoyancy.

\section{Dynamic Systems: Margins of Africa}

The Margins of Africa research theme will investigate the causes and consequences of the breakout of southern Africa from its Gondwana configuration. Central to this research is a series of onshore-offshore geophysical transects across the three different continental margin types of South Africa. The first of these amphibian experiments, across two margins, were completed between 2003 and 2005 (Figure 2 and below). The western (Atlantic) margin is a classic volcanic rifted margin, with associated flood basalts and prominent seaward dipping reflector sequences and high-velocity underplated offshore crust.

In 2004 , two transects were acquired that had lengths of 500 kilometers each and covered the entire transition, from the deep oceanic basin to the stable continent. Offshore, the surveys included reflection and refraction seismic measurements using 2300 airgun shots and seven ocean-bottom hydrophones (OBHs). The refraction experiments extended on land for approximately 150 kilometers, recording three borehole shots with three-component sensors at all 40 stations. Preliminary velocity models reveal a much smaller volume of underplated lower crust compared with existing transects to the north, yet the volume of seaward dipping reflector sequences here is larger. New dating of magnetic anomalies also suggests that the basaltic activity is significantly older in the south. These and other data will detail the early opening of the South Atlantic.

The southern margin transect stretches from the oceanic Agulhas Plateau, across the Falkland-Agulhas shear zone that dominates the sharp continent-ocean boundary at the continental shelf, and from there extends 240 kilometers inland crossing the Cape Fold Belt and the Karoo basin with its underlying approximately one-billion-year-old continental crust. This includes the Beattie magnetic anomaly (the world's largest terrestrial magnetic anomaly) and the enigmatic Southern Cape Conductive Belt. Onland, high-resolution magnetotelluric (MT) data were recorded in late 2004, at 82 sites with an average site spacing of two kilometers in the frequency range from 1000 to $0.001 \mathrm{~Hz}$.

These new data reveal a zone of high electrical conductivity associated with the Beattie magnetic anomaly at a depth of approximately 5-10 kilometers. The MT pro-

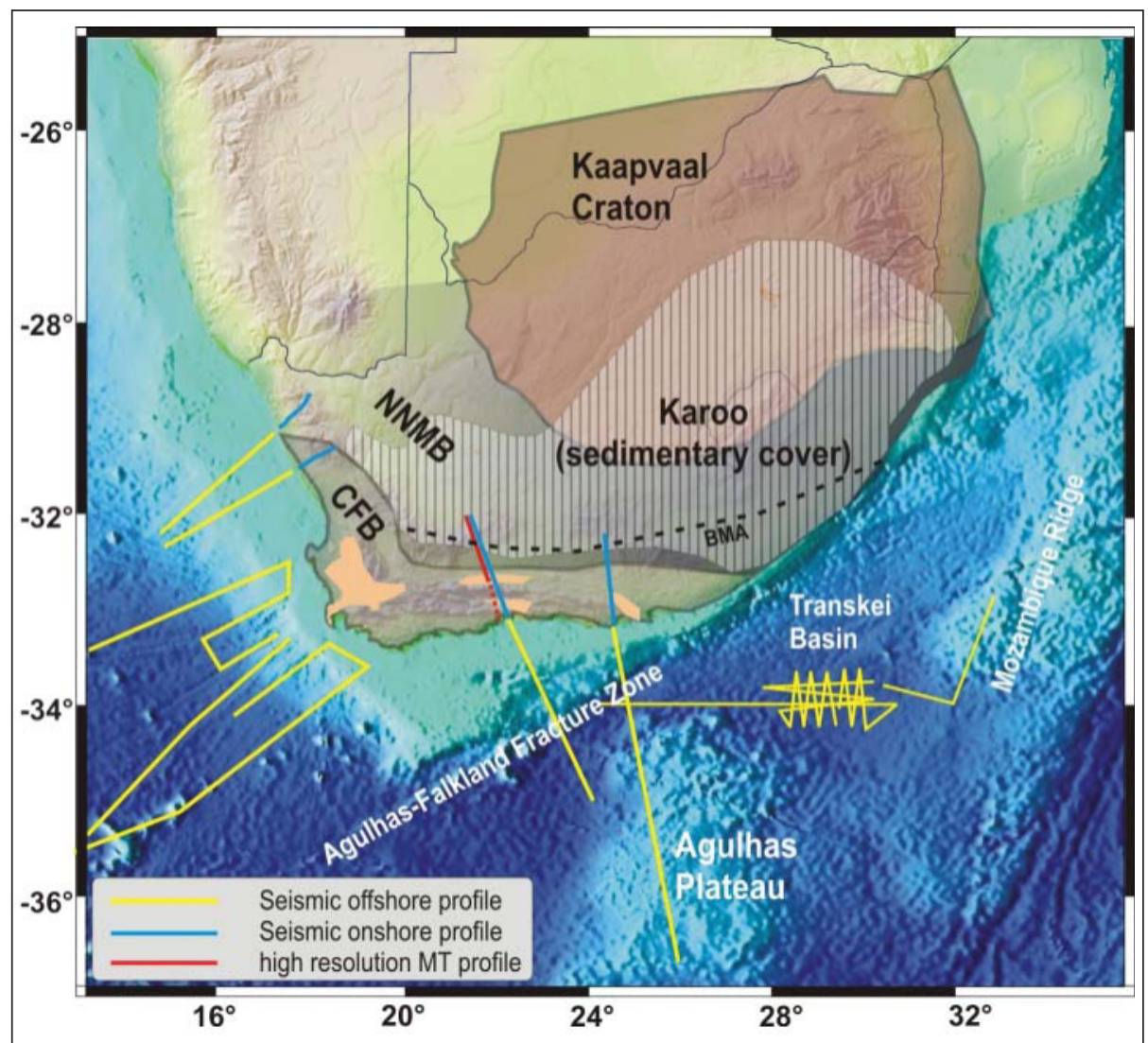

Fig. 2. Locations of Inkaba yeAfrica's marine geophysical studies, amphibian seismic reflection/ refraction profiles across the continental margins of South Africa, and a terrestrial magnetotelluric (MT) profile. NNMB is the Namaqua Natal Mobile Belt, CFB is the Cape Fold Belt, and BMA is the Beattie magnetic anomaly.

file was continued southward in late 2005.

Complementary seismic data were recorded in 2005 along two refraction lines, each with a length of 240 kilometers, 48 stations, and 13 borehole shots. Offshore, these were extended along a 400-kilometer western profile and a 700-kilometer eastern profile, deploying 20 and 29 OBHs, respectively. Preliminary analysis confirms excellent data quality with upper mantle refraction phases observed at up to 200-kilometer offset.

In addition, the first of a series of planned cruises to examine the magnetic signatures and petrology (through dredge hauls) of poorly surveyed oceanic crust and ridges in the study region was successfully completed in mid-2005 across the Mozambique Ridge and Basin. These 'missing links' are crucial to tracking the opening of the southern oceans with the detail that is now required to test Earth system feedback loops.

\section{Dynamic Systems: Living Africa}

The third theme, Living Africa, consists of several integrated programs focused on resolving the stratigraphic records on the continental margins and inland lake and cave deposits, to establish linkages among sedimentation, tectonics, sea level, oceanatmosphere circulation, and carbon storage.

A gas-system project, using existing threedimensional seismic and well data, has con- structed a dynamic tectonostratigraphic basin model of the Atlantic margin that, coupled with heat flow, will explore feedback loops to predict and test generation and migration of hydrocarbons and their expulsion into the ocean-atmosphere system. Preliminary results reveal extensive, stratigraphically-controlled gas-seepage events (Figure 3).

Related projects are starting to resolve details of the major reorganization of the currents of the southern oceans following the opening of the Drake Passage (30-35 Ma). Fine-scale chemical stratigraphy along the Atlantic margin and seismic stratigraphy across the Agulhas Plateau show that strong Antarctic bottom-water currents were active around southern Africa by the Oligocene Epoch (23-34 Ma), and that significant upwelling and migration of the Benguela Current started in the Miocene Epoch (by about $24 \mathrm{Ma}$ ). Within the last two million years, this shelf evolved into a major sink for terrigenous mud and organic matter to support feedback links of the carbon subcycles that track glacial to interglacial fluctuations.

At a higher resolution, decadal and centennial records of recent times on this shelf are being linked to terrestrial records of megaflood events, and to past precipitation patterns across southern Africa by using proxies from cave stalagmites and cored lake deposits. Biomarkers are being used to track ecological changes. Collectively, these projects will provide a high-resolution his- 
Eos, Vol. 87, No. 11, 14 March 2006

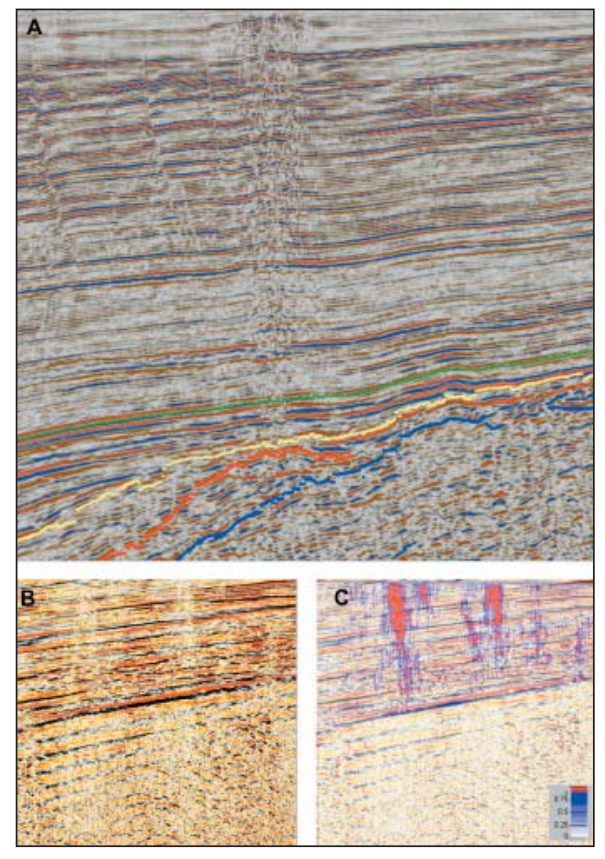

Fig. 3. The coupling of the geosphere and atmosphere is being examined in the Orange Basin using seismic stratigraphy, basin modeling, and hydrocarbon seep analysis. Major gas seeps occur at stratigraphic pinch-outs (a).To quantify gas escape, subtle as well as major seeps have to be recognized. Therefore, seismic attributes have been used to train a neural network (b), and the trained neural network then recognizes subtle seepage phenomena, as illustrated for the same profile (c).

tory of coupled ocean-atmosphere-biosphere climate changes and the coevolution of Earth and life-support systems.

\section{Capacity Building in Africa}

During a previous large collaborative Earth science project with the United States, which was completed in 2003, the South African geoscience community established a successful record of public outreach programs and human capacity building that included graduate programs specifically designed for students from previously disadvantaged backgrounds [Tredoux and Webb, 2004]. Inkaba yeAfrica will build further on this. To date, scientists have designed rural community teaching projects. Up to $60 \mathrm{stu}-$ dent scholarships are available. South African and German students participate together in field experiments and ocean cruises, and South African students follow

Table 1. Inkaba yeAfrica ongoing projects, unless indicated otherwise

\begin{tabular}{|c|c|c|}
\hline Themes & Projects & \multirow{4}{*}{ 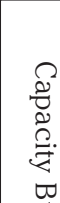 } \\
\hline \multirow{4}{*}{ Heart of Africa } & Earth and Ocean Monitoring Network across southern Africa & \\
\hline & Morphology of geomagnetic field variations in southern Africa & \\
\hline & Epeirogenic history of southern Africa & \\
\hline & Rock burst and earthquake hazards in deep gold mines & $\underline{\underline{z}}$ \\
\hline \multirow{4}{*}{ Margins of Africa } & The Western (Atlantic) Margin & $\overrightarrow{30}$ \\
\hline & The Southern Margin - the Agulhas-Karoo Geoscience Transect & $\cong$ \\
\hline & The Southeastern Margin (start 2007) & 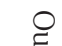 \\
\hline & Dredging of the Walvis Ridge, MeteorRise - Shona Ridge (start 2006) & $\overrightarrow{\bar{D}}$ \\
\hline \multirow{4}{*}{ Living Africa } & Generation, migration and sequestration of natural gas & \multirow{4}{*}{$\begin{array}{l}0 \\
0 \\
0 \\
0 \\
00 \\
0 \\
3 \\
3\end{array}$} \\
\hline & Seismic stratigraphy of the South African margins & \\
\hline & Neogene-Quaternary palaeoceanography & \\
\hline & Past precipitation pattern of South Africa & \\
\hline
\end{tabular}

up with extended periods in Germany for training in a variety of disciplines.

Annual workshops rotate between South Africa and Germany; the next workshop is on 1-3 June 2006 in Potsdam.

Details on all of the projects and participants are available at http://www.hartrao.ac. za/inkaba/index.php and http://www. gfz-potsdam.de/pb4/pg3/projects/INKABAye AFRICA/index_en.html

\section{Acknowledgements}

We thank Rolf Emmermann for initiation and sustained encouragement of Inkaba yeAfrica; Khotso Mokhele; Gerhard von Gruenewald; Robert Kriger; Zvi Ben Avraham, and Rod Green for unwavering help; and farmers for access to their land, companies to their deep mines, and the Petroleum Agency of South Africa to its database. The project is supported in Germany by GeoForschungsZentrum Potsdam, the Alfred Wegener Institute, the Bundesanstalt für Geowissenschaften und Rohstoffe, and the German Federal Ministry of Education and Research; and in South Africa by the Department of Science and Technology, the National Research Foundation, the Council for Geoscience, Hartebeest Radio Astronomy Observatory, Hermanus Magnetic Observatory, and the University of Cape Town.

This article was written in collaborative interaction with the following colleagues: Ludwig Combrinck, John Compton, Luc Chevalier, Coenie de Beer, Reginald Domoney, Alex Kounov, Pieter Kotze, Anton le
Roex, David Reid, Steve Spottiswoode, Peter Sutcliff, Justine Tinker, Marian Tredoux, Tim Partridge, George Smith, Mike Watkeys, Sue Webb (South Africa); Burkhard Buttkus; George Dresen, Jörg Erzinger, Karsten Gohl, Wilfried Jokat, Sönke Neben, Mioara Mandea Jürgen Neumeyer, Samuel Niedermann, Hedi Oberhänsli, Rolando di Primio, Oliver Ritter, Trond Ryberg, Rob Trumbull, Gabriele Uenzelmann-Neben, Michael Weber, Ute Weckmann, and Heinz Wilkes (Germany), all from the Inkaba yeAfrica Working Group, and with a special thanks to Miora Mandea for getting this report started. This is Inkaba yeAfrica contribution 001 .

\section{References}

Bohannon, J. (2004), Earth sciences seek niche apart from mining industry Science, 304, 380-381.

Tredoux, M., and S. Webb (2004), Research capacity building in Africa as part of international programmes: Experience gained from the Kaapvaal Craton project, S. Afr. J. Geol., 107, 7-12.

\section{Author Information}

Maarten de Wit,Africa Earth Observatory Network, University of Cape Town, Rondebosch, South Africa, and GeoForschungsZentrum Potsdam (GFZ-Potsdam), Germany, E-mail: maarten@cigces. uct.ac.za; Brian Horsfield, GFZ-Potsdam, E-mail: horsf@gfz-potsdam.de 